selectivity is necessary and the latest dispute seems to be over which programmes the agency should concentrate on. The principal candidates are telecommunications, space transportation systems and Earth resources, with Spacelab and rocket-borne micro-gravity experiments a minor option.

The option standing the greatest chance of success is the Earth resources project. Many member states agree that Europe should be more active in the field, and a decision is due later this year on whether to go ahead with ERS 1, ESA's first remote sensing satellite for oceanographic studies. A more controversial plan for future Earth resources satellites is also to be planned.

But the greatest dispute is over what should be done about telecommunications, supported by Britain, Italy and the smaller countries, and space transportation systems, supported by France. France and Germany, by far the biggest space spenders inside and outside the agency, opted out of ESA's Large Commununications Satellite (L-sat) when they decided to build jointly a large satellite for direct broadcasting. Both countries would prefer telecommunications satellites, already showing commercial potential, to be built outside ESA which is primarily a research and development agency.

The future of L-sat will probably be assured later in the year when Britain, Italy and the smaller nations give it their approval. The question then will be whether to build the next generation of advanced telecommunications satellites within the agency or within French and German industry. The issue is particularly sensitive for Britain, which has recently

\section{One step to LEP}

The UK Advisory Board for the Research Councils has recommended to Secretary of State Mark Carlisle that Britain should support LEP - the SF 960 million electron-positron collider planned for the European subnuclear physics laboratory, CERN, near Geneva. If Mr Carlisle accepts the board's advice, British delegates at CERN's June council meeting will vote for LEP to be included as an integral part of CERN's future programme, not as a separate project as some factions - particularly in Sweden - would like.

Meanwhile, LEP has shrunk - if not in cost, in size. A new design has LEP only $27 \mathrm{~km}$ in circumference, so only $8 \mathrm{~km}$ of the accelerator tunnel will be under the French Jura Mountains to the north of the CERN site. In this way LEP will avoid a region of fractured and unstable rock the "trias" - which was threatening substantial increases in civil engineering costs. Improvements in machine design will enable the new LEP to reach the same energy without any increase in power consumption.

Robert Walgate decided to built up its telecommunications industry in the hope that ESA could provide more support.

The dispute has driven the ESA members into two camps - the smaller countries led by Britain, and France and Germany who put up most of the money for Ariane and Spacelab. It is feared that France and Germany could decide to contribute even less to the agency than M. Quistgaard's plan envisages, preferring instead to put more money into their own well-developed space industries. That could weaken the agency to the point where it could not afford to run its own basic support facilities. As yet, however, according to one official, nothing is certain and anything is possible. The next few months should determine the future.

Judy Redfearn

\section{Chemical warfare}

\section{Budget increase}

\section{Washington}

The first signs that President Reagan will implement his election promise to produce chemical weapons came last week in the Defense Department's budget proposals. The Pentagon has confirmed that the $\$ 222,200$ million budget for the next fiscal year will include $\$ 20$ million for construction work on a plant at the Pine Bluffs arsenal in Arkansas for producing binary chemical weapons.

Provisional approval for the building of the plant was given by Congress last year, but since then there has been intense lobbying by church groups and other protesters, while the previous Defense Secretary, Harold Brown, was lukewarm on the project. This is why funds for the first stage of its construction were not included in President Carter's budget submitted to Congress early in January.

Pentagon officials are at pains to emphasize that the request for $\$ 20$ million does not necessarily mean that Mr Reagan plans to end the moratorium on the production of chemical weapons begun by President Nixon in 1970. But they think that the new president is "leaning in that direction" and that his second budget a year from now would ask for a further $\$ 140$ million to build full-scale manufacturing facilities.

Throughout the past decade, the US Army has kept up the pressure for reduced production, arguing that even if only a small stockpile of chemical weapons were required for deterrence, binary weapons could be stored more safely than those in which active chemical agents are present from the start. For some time, the army has been embarrassed by the leakage of nerve gas from "Weteye" bombs stored in Colorado.

Congress refused to fund the construction of binary weapons in 1975 and 1976, with the result that the US Army's interest in going ahead was dis- couraged by the White House in succeeding years. There is, however, evidence that President Carter may have relaxed his previous opposition to chemical weapons shortly before leaving office. The Arms Control and Disarmament Agency said, when the president's last budget was published in January, that the Administration had agreed to an increase of chemical weapons activity within the Defense Department. The agency estimated that expenditure would grow from $\$ 2$ million in the fiscal year 1981 to $\$ 14.4$ million in 1982.

Among the projects foreseen in the Carter budget were the experimental development of new binary weapons $(\$ 2.2$ million) and the development of a binary spray bomb in which all three services had an interest. Production of this weapon, called "Bigeye", will require both presidential and congressional approval, as will the production of the 8-inch and $155-\mathrm{mm}$ artillery projectiles now under development. One of the issues that will concern both the White House and Congress is the effect of a decision to resume production on the negotiations with the Soviet Union on a chemical disarmament treaty, which has been discussed in Geneva since August 1976.

The Defense Department also asked Congress in January for $\$ 44$ million for "chemical defense science and technology" projects in 1982. This is considerably higher than in previous years, and follows recommendations about necessary improvements to protective equipment, warning devices and medical treatment made last summer in a study conducted by the Defense Science Board.

David Dickson

\section{Allen's successor}

Professor John Kingman is to be the next chairman of the Science Research Council. He will take over from Sir Geoffrey Allen, who is returning to his old research group at Imperial College, on 1 October.

Professor Kingman, who will be leaving his niche as professor of mathematics at the University of Oxford, is an unusual choice, having had no experience of experimental science. His work has been in mathematics and statistics. Since 1979, however, he has been chairman of the council's science board. The board's zeal for awarding research grants was largely responsible for overspending by the council to the tune of $£ 10$ million in 1979-80.

The Department of Education and Science, which made the appointment, had apparently hoped to boost the council's image as a supporter of biological sciences by appointing a biologist, but no willing candidates could be found.

Judy Redfearn 